\title{
FUNDAMENTALS OF DEVELOPING FINE GRAINED STRUCTURES IN “AS ROLLED” LONG PRODUCTS*
}

Douglas Glenn Stalheim ${ }^{1}$ Michael Robert Wright ${ }^{2}$

\begin{abstract}
The demands for improved mechanical properties in hot rolled long products are increasing as the expectations of global Standards and construction designer's increase. Cost constraints limit the excessive use of expensive alloys to meet these expectations. In addition, depending on the mill, equipment can limit what can be realized to meet the increasing expectations. The most effective way to meet the increasing expectations for improved mechanical properties of optimum strength and ductility is through producing steel with as fine as possible uniform cross sectional grain size in the "as-rolled" condition. The best solution to the development of this fine and uniform cross sectional grain size is to develop a cost effective alloy design coupled with proper metallurgical process control implemented into an existing mill's equipment capability and layout. In other words, properly bringing together alloy, metallurgy, process control and existing equipment capabilities to develop an optimum product that can meet the increasing demands of the construction designer. This paper is designed to give a solid understanding of the production and metallurgical requirements to achieve a grain size in "as-rolled" long products that is as fine as possible within the limitations of the process and production parameters of the individual plant.
\end{abstract}

Keywords: Fine Grained; Long Products; Process Control; Metallurgy.

1 Bachelor of Science in Metallurgical Engineering, South Dakota School of Mines and Technology, USA, President, DGS Metallurgical Solutions, Inc., Vancouver, WA USA.

2 Bachelor Applied Science (Materials), University of Technology, Sydney, Australia, Managing Director-Modern Metal Solutions Pte Ltd, Singapore.

* Technical contribution to the 51st Rolling Seminar - Processes, Rolled and Coated Products, October $28^{\text {th }}$ to $31^{\text {st }}, 2014$, Foz do Iguaçu, PR, Brazil. 


\section{INTRODUCTION}

Demands are increasing on structural steels for higher strength, elongation and toughness to support new building codes for improved safety standards, especially those in seismic areas. For any microstructure design the maximum strength, elongation and toughness is achieved by producing as fine as possible final transformed grain size for that microstructure. Between $40-70 \%$ of a given steels strength comes from the grain size as illustrated in Figure 1 [1].

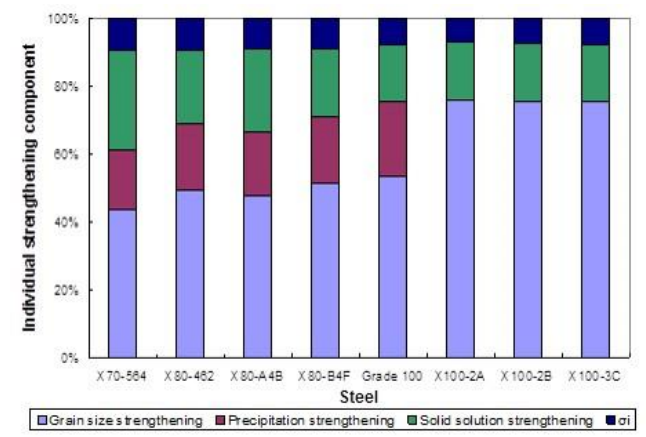

Figure 1. Illustration of the strengthening components of structural steel

A structural steel having a greater number of smaller grains is said to have a "fine grain size". ASTM (American Standards and Testing Methods) defines anything having an average grain size of $65 \mu \mathrm{m}$ (ASTM GS 5) or smaller as fine grain. Anything larger than $65 \mu \mathrm{m}$ is considered coarse grain. From experience in long/structural products with desired properties shown Table 1 will require final transformed grain sizes in the ASTM 9 or finer, $<20 \mu \mathrm{m}$.

Table 1. Typical long products mechanical properties requiring ASTM 9 or finer

\begin{tabular}{|c|c|c|c|}
\hline $\begin{array}{c}\text { Yield Strength } \\
(\mathrm{MPa})\end{array}$ & $\begin{array}{c}\text { Elongation } \\
(\%)\end{array}$ & $\begin{array}{c}\text { Agt } \\
(\%)\end{array}$ & $\begin{array}{c}\text { Impact }(\mathrm{J}) \\
(0 \mathrm{C} \text { to }-40 \mathrm{C})\end{array}$ \\
\hline$>450$ & $>25 \%$ & $>13 \%$ & $>100$ \\
\hline
\end{tabular}

Figure 2 shows examples of various ASTM grain size, however one must note that not all "fine grains" are created equal when it comes to mechanical property performance of structural steels.

\section{GRAIN SIZE EVOLUTION}

The final transformed grain size in structural steel is achieved by processing (reheating, rolling/deformation and cooling) and the presence of a micro-alloy, in particular niobium. Contrary to popular belief aluminium does not contribute to the asrolled final transformed grain size in structural steels. If no niobium is present, then the production of structural steels is done purely by what is termed recrystallized rolling. If niobium is present then the final transformed grain size evolution is affected by a combination of recrystallized rolling plus a non-recrystallized rolling regime.

\footnotetext{
* Technical contribution to the 51st Rolling Seminar - Processes, Rolled and Coated Products, October $28^{\text {th }}$ to $31^{\text {st }}$, 2014, Foz do Iguaçu, PR, Brazil.
} 


\section{$\underset{\text { Rolling }}{\text { LAMINAÇÃO }}$}
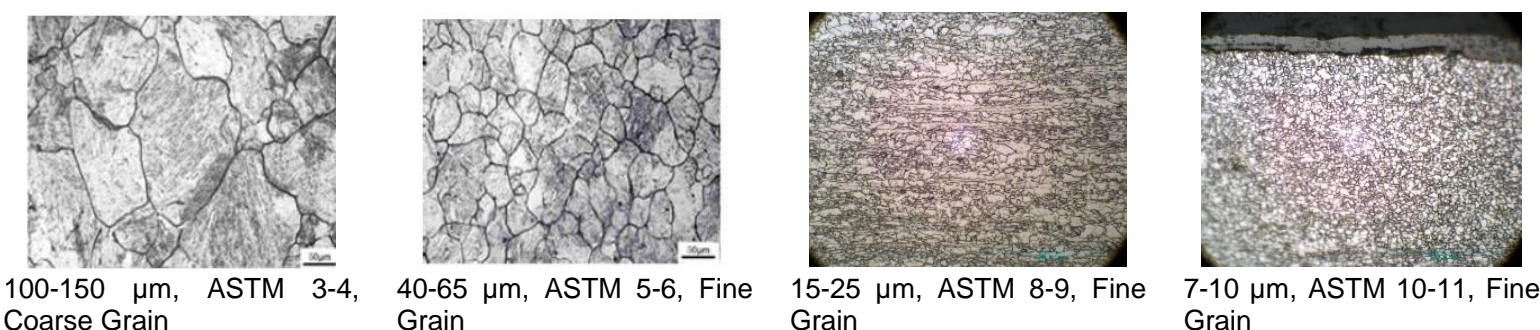

Figure 2. Examples of various ASTM grain sizes

Recrystallized rolling is typically called "hot rolling" or "controlled rolling", if the final rolling temperature is controlled. Recrystallized plus non-recrystallized rolling can also be called controlled rolling (final temperature is controlled and/or an intermediate temperature is controlled) or it is termed thermo-mechanical control processing (TMCP) where final rolling temperature is controlled AND an intermediate temperature is controlled along with a specific amount of deformation below the temperature of non-recrystallization, Tnr.

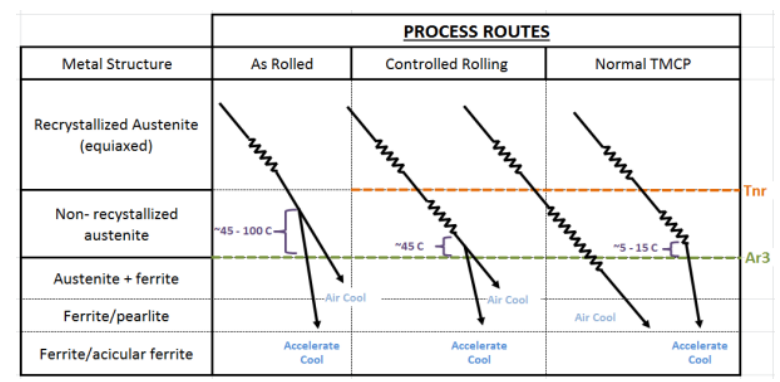

Figure 3. Schematic of various process routes used for creating grain size

Figure 3 shows a schematic of the various rolling strategies (as- rolled, controlled rolling, TMCP) used to develop grain size [2].

Figures $4 a$ and $4 b$ [3] illustrate the differences in recrystallized (hot rolling) vs. recrystallized rolling plus non-recrystallized rolling (TMCP) and grain size evolution.

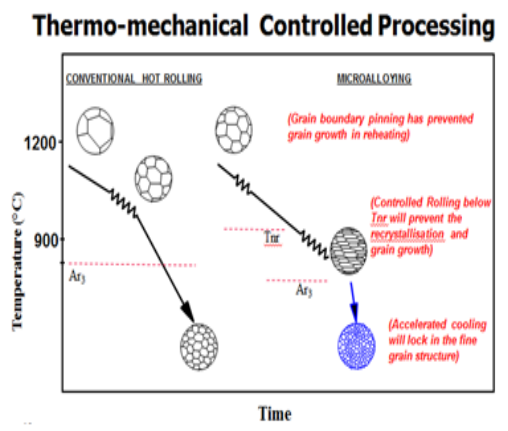

a) Comparison of recrystallized vs. nonrecrystallized grain size evolution

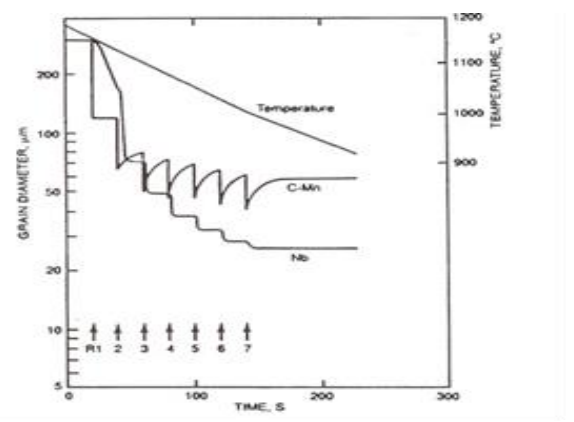

b) Comparison of recrystallized C-Mn steel with deformation and $\mathrm{C}-\mathrm{Mn}-\mathrm{Nb}$ steel with nonrecrystallized deformation grain size evolution.

Figure 4. Grain size evolution through recrystallized and non-recrystallized processing

In recrystallized rolling, the finest final transformed grain size that can be achieved is ASTM $9(\sim 16-20 \mu \mathrm{m})$. This is only possible if the recrystallized rolling process has been fully optimized. An illustration of recrystallized deformation and grain size formation can be seen in Figure 5 [4].

* Technical contribution to the 51st Rolling Seminar - Processes, Rolled and Coated Products, October $28^{\text {th }}$ to $31^{\text {st }}, 2014$, Foz do Iguaçu, PR, Brazil. 

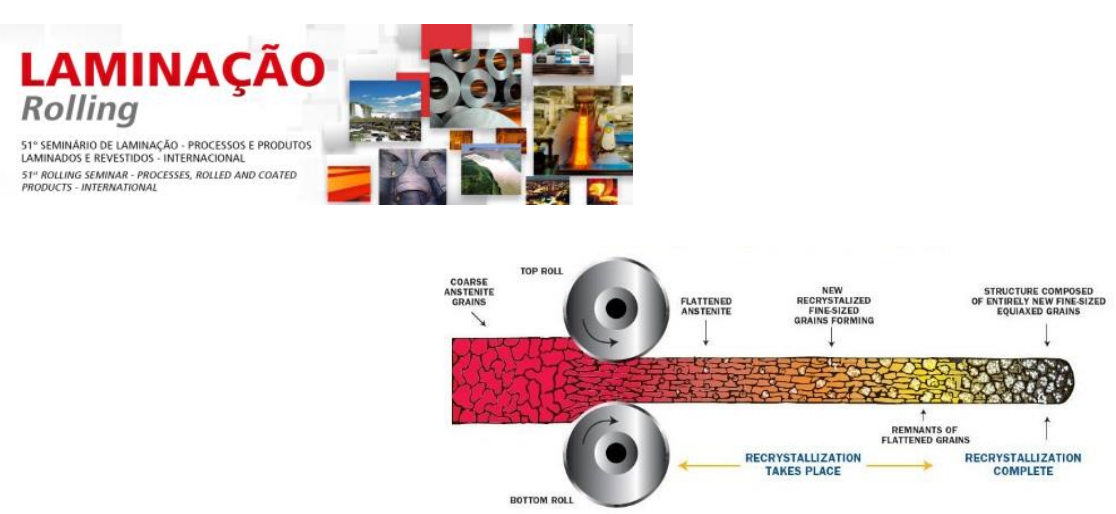

Figure 5. Illustration of recrystallized rolling grain size evolution

If a finer grain is required for higher strength, elongation or toughness than a combination of recrystallized and non-recrystallized rolling utilizing niobium microalloy technology has to be used, Figure 6.

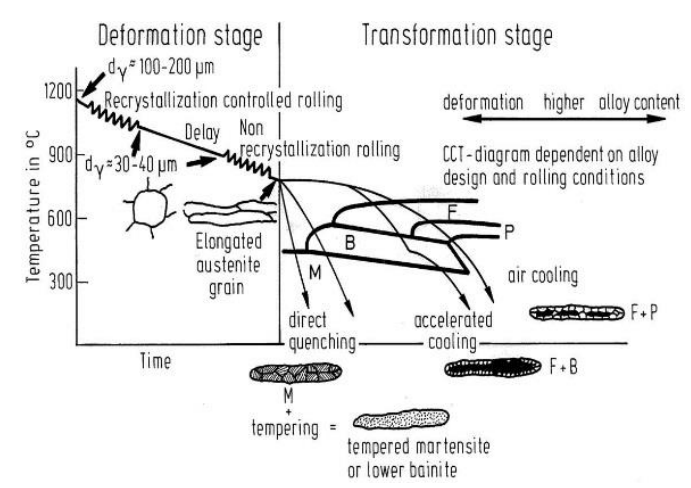

Figure 6. Schematic of grain size evolution through a combination of recrystallized and nonrecrystallized deformation plus cooling processing.

As stated prior, fine grain is defined by ASTM standards as anything that has an average grain size of $65 \mu \mathrm{m}$ (ASTM $5-12$ ). Recrystallized processing is capable of producing grain size in the 20-65 $\mu \mathrm{m}$ range (ASTM 5-9). For modern steel requirements with higher strength and elongation and improved toughness, then finer grains are needed, and a recrystallized plus non-recrystallized processing will be required to produce grains from 5-20 $\mu \mathrm{m}$ (ASTM 10-12). As stated prior there is a very large difference in mechanical properties in steels with ASTM 5-9 grain size vs. those with ASTM grains in the 10-12 range. Figure 7 shows the range of grain sizes produced by the two metallurgical processes, optimized and non-optimized [5].

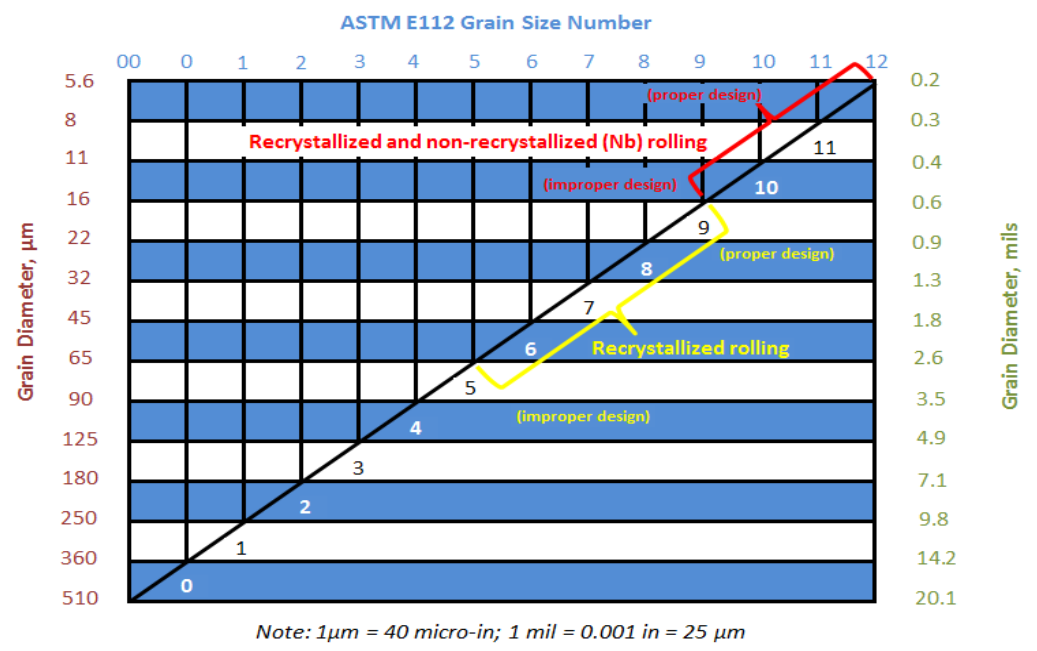

Figure 7. Illustration of processing vs. grain size created in the production of fine grain structural steels

* Technical contribution to the 51st Rolling Seminar - Processes, Rolled and Coated Products, October $28^{\text {th }}$ to $31^{\text {st }}, 2014$, Foz do Iguaçu, PR, Brazil. 

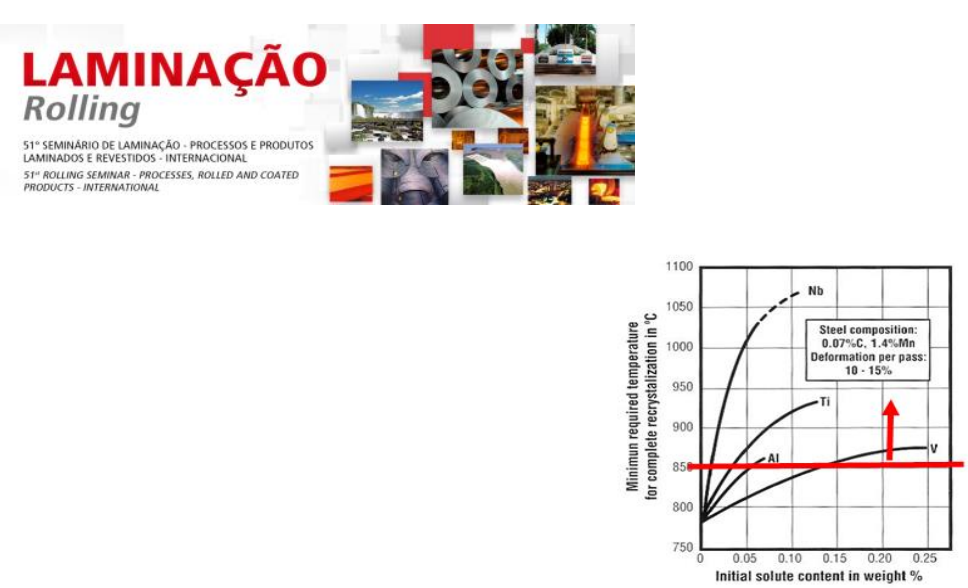

Figure 9. Micro-alloy capability to prevent recrystallization from occurring. Line and arrow show typical long/structural products minimum processing temperature

In regard to control of austenite grain during reheating, niobium and titanium both can work as described prior. Aluminum does not contribute to controlling grain size in hot rolled structural steels as it is in solution during reheating and only forms inclusions during hot rolling. Aluminum should only be used as a deoxidizer during steelmaking and used at a level, $0.015-0.030 \%$ (with a target of $0.020-0.025 \%$ ) that only meets minimum specification requirements. Vanadium is also in solution during reheating and only contributes as a precipitation strengthening mechanism if properly controlled during final cooling after rolling. Titanium can help control austenite grain size during reheating as discussed and at high levels can contribute to precipitation strengthening mechanisms along with a very minor, but most likely negligible contribution to non-recrystallized deformation. Niobium is the only microalloying element that can play two roles in controlling the final transformed ferrite grain size through $\mathrm{NbCN}$ precipitate austenite grain size pinning during reheating and preventing recrystallization during typical hot rolling temperatures for long/structural products. In addition, depending on Niobium level, some Niobium precipitate formation during final cooling can contribute to precipitation strengthening. If pure recrystallized deformation is going to be used, the niobium level can be designated to a level (depending on $\mathrm{C}, \mathrm{N}$, reheat temperature and time) to control the austenite grain size only during reheating. In this fashion, coupled with optimized deformations during rolling, an ASTM 8-9 $(15-25 \mu \mathrm{m})$ cross sectional grain size may be realized. If a finer ASTM grain size is required, as it most likely will be with today's specification requirements for long/structural products, then the niobium design should be such to control both reheating austenite grain size and create some level of nonrecrystallized deformation.

The key points to optimizing the final transformed grain size in long/structural products are as follows:

1. Designing the niobium level to allow for some $\mathrm{NbCN}$ precipitate to control the reheat austenite gain size and have enough $\mathrm{Nb}$ in solution to develop a nonrecrystallization (Tnr) temperature that is within the rolling capability of the mill.

2. Taking a good reduction during recrystallized rolling at the ideal cross section to homogenize the surface to center austenite grains.

3. Applying some water cooling along the rolling train to reduce the temperature to match the non-recrystallized (Tnr) temperature to realize some volume fraction of non-recrystallized deformation to occur.

4. Post rolling cooling to minimize any post rolling grain growth before transformation occurs. Calculation of the transformation start temperature $\mathrm{Ar}_{3}$ is needed to define transformation start relative to the finish rolling temperature and post rolling cooling stop temperature.

5. For information precipitation strengthening occurs for $\mathrm{Nb}$ and $\mathrm{V}$ in the $600{ }^{\circ} \mathrm{C}$ range and for $\mathrm{Ti}$ in the $700{ }^{\circ} \mathrm{C}$ range.

\footnotetext{
* Technical contribution to the 51st Rolling Seminar - Processes, Rolled and Coated Products, October $28^{\text {th }}$ to $31^{\text {st }}, 2014$, Foz do Iguaçu, PR, Brazil.
} 


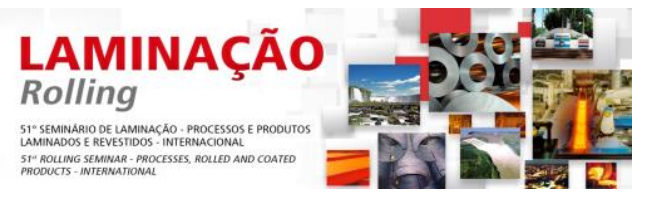

Not all key parameters may be possible, but if parameter points 1 and 2 can be accomplished at a minimum grain size will improve resulting in some improvement in final mechanical properties. The more that can be done the further up the ASTM grain size line as seen in previous Figure 7 will be achieved, i.e. ASTM 8 is better than ASTM 7 and ASTM 9 is better than ASTM 8 etc.

\section{DISCUSSION ON KEY PROCESS PARAMETERS}

Niobium carbonitride dissolution temperature can be calculated per the following equation:

$$
\log [\mathrm{Nb}][\mathrm{C}+12 / 14 / \mathrm{N}]=2.26-6770 / \mathrm{T} \quad \text { (Irvine) }
$$

If for some reason titanium is part of the alloy design then the niobium carbide $(\mathrm{NbC})$ dissolution temperature should be calculated also per the following equation:

$$
\log [\mathrm{Nb}][\mathrm{C}]=2.96-7510 / \mathrm{T} \quad \text { (Hulka) }
$$

By calculating one or both key temperature values, billet reheating temperature can be determined for a given Niobium level and a determination can be made if the Niobium level is sufficient to have enough Niobium available for reheat austenite grain pinning, Figure 10.

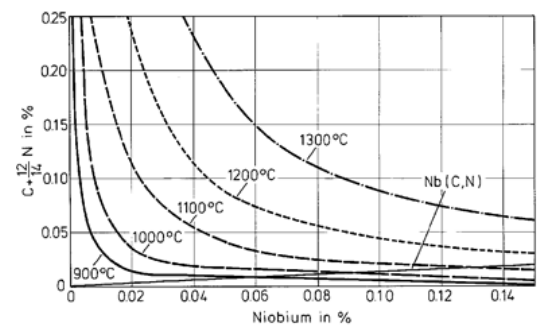

Figure 10. $\mathrm{NbCN}$ vs. reheat temperature vs. various starting $\mathrm{Nb}$ levels

Based on the aim billet temperature, the amount of $\mathrm{Nb}$ in solution can be determined. This can be used to calculate the non-recrystallized (Tnr) temperature bracket using the following equations:

${ }^{\circ} \mathrm{C}=\left(887+464^{\star} \mathrm{C}+890\left(\mathrm{Ti}^{\star} 0.80\right)+363\left(\mathrm{Al}^{\star} 0.80\right)-357^{\star} \mathrm{Si}\left(\mathrm{Si}^{*} 0.80\right)+\left(6445^{\star}\left(\mathrm{Nb}^{\star} 0.80\right)-\right.\right.$ $644^{\star}\left(\mathrm{SQRT}\left(\mathrm{Nb}^{*} 0.80\right)\right)+\left(732^{*}\left(\mathrm{~V}^{\star} 0.80\right)-230^{*}\left(\mathrm{SQRT}\left(\left(\mathrm{V}^{\star} 0.80\right)\right)\right)\right.$ (Boratto/ DGS Modified based on practical experience)

$$
{ }^{\circ} \mathrm{C}=\left(\left(174^{\star} \log \left(\mathrm{Nb}^{*}\left(\mathrm{C}+12 / 14^{*} \mathrm{~N}\right)\right)+1444\right)-75^{\circ} \mathrm{C}\right.
$$

The final calculation is to determine the start of transformation, $\operatorname{Ar}_{3}$ using this equation:

${ }^{\circ} \mathrm{C}=\left(1670-588^{*}(\mathrm{C}+(\mathrm{Mn}+\mathrm{Mo}) / 3.875+\mathrm{Cu} / 15.5+\mathrm{Cr} / 20.67+\mathrm{Ni} / 5.636)+16^{*}\right.$ (thickness $)-$ $0.315)-32)^{\star} 5 / 9$ (Ouchi - DGS Modified)

An example of how this can be used can be seen in Table 2 below.

* Technical contribution to the 51st Rolling Seminar - Processes, Rolled and Coated Products, October $28^{\text {th }}$ to $31^{\text {st }}$, 2014, Foz do Iguaçu, PR, Brazil. 


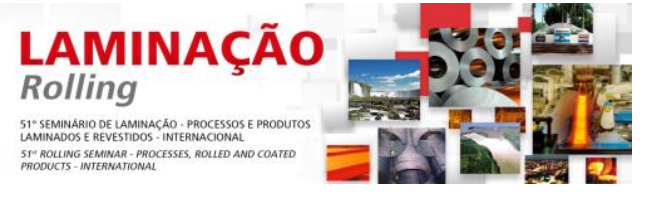

Table 2: Example of alloy design and corresponding key metallurgical process parameters

\begin{tabular}{|c|c|c|c|c|c|c|c|c|c|c|}
\hline$C$ & $\mathrm{Mn}$ & $\mathrm{Si}$ & $\mathrm{Al}$ & $\mathrm{Nb}$ & $\mathrm{V}$ & $\mathrm{Ti}$ & $\mathrm{N}$ & $\begin{array}{l}\text { Section } \\
(\mathrm{mm})\end{array}$ & $\begin{array}{l}\text { Reheat } \\
\left({ }^{\circ} \mathrm{C}\right)\end{array}$ & \\
\hline 0.20 & 1.30 & 0.25 & 0.025 & 0.030 & 0.040 & $\leq 0.005$ & \begin{tabular}{|l|l|} 
& 0.010 \\
\end{tabular} & 20 & 1150 & \\
\hline \multicolumn{3}{|c|}{$\begin{array}{c}\text { NbCN Solution } \\
\left({ }^{\circ} \mathrm{C}\right)\end{array}$} & \multicolumn{2}{|c|}{$\begin{array}{l}\text { NbC Solution } \\
\left({ }^{\circ} \mathrm{C}\right)\end{array}$} & \multicolumn{2}{|c|}{\begin{tabular}{c|c} 
Nb in & \\
Solution &
\end{tabular}} & \multicolumn{2}{|c|}{$\begin{array}{l}\text { Tnr - Boratto /DGS } \\
\text { Modified }\left({ }^{\circ} \mathrm{C}\right)\end{array}$} & $\begin{array}{c}\text { Tnr - Bai } \\
\left({ }^{\circ} \mathrm{C}\right)\end{array}$ & $\operatorname{Ar}_{3}\left({ }^{\circ} \mathrm{C}\right)$ \\
\hline \multicolumn{3}{|c|}{1244} & \multicolumn{2}{|c|}{1176} & \multicolumn{2}{|c|}{0.015} & \multicolumn{2}{|c|}{906} & 933 & 746 \\
\hline
\end{tabular}

Based on the example in Table 1, $0.015 \% \mathrm{Nb}$ would be in the form of $\mathrm{NbCN}$ to help control austenite grain size during reheating and $0.015 \%$ is in solution and contributes to the generation of a non-recrystallized temperature (Tnr). So in designing the rolling process from a temperature point of view using the above values, if the surface or even better yet the entire cross section of the thickness is below a temperature in the $906-933^{\circ} \mathrm{C}$ range at some point during the deformation, then some level of non-recrystallized deformation can be realized resulting in the potential of a finer transformed ferrite grain size.

Post rolling cooling to around $750^{\circ} \mathrm{C}$ based on the $\mathrm{Ar}_{3}$ temperature will help control any post rolling grain growth and still be high enough to promote any precipitation strengthening mechanism to occur from the $\mathrm{Nb}$ and $\mathrm{V}$ in the Table 1 example.

An example of various percent deformation in the non-recrystallized rolling region and its effect on charpy toughness transition, which is indirect measurement of the level of fine grain produced can be seen in Figure 11. From Figure 11 one can see that even a small amount of deformation, $10-20 \%$, in the non-recrystallized rolling region can be beneficial.

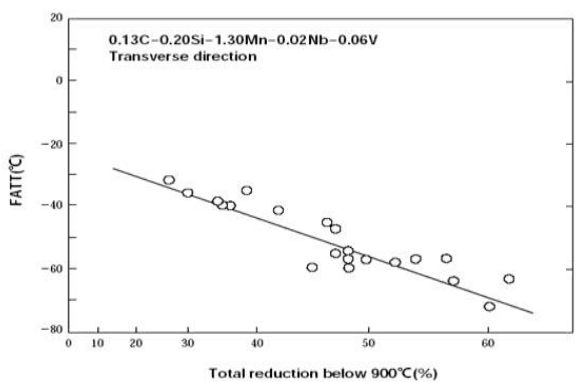

Figure 11. Example of \% deformation below the Tnr vs. charpy transition temperature

In addition, if an optimum reduction, $>15 \%$ can be taken at a critical thickness then the cross sectional austenite grain size can be as fine and as homogenous as possible. The goal is 30-40 $\mu \mathrm{m}$ which will result in a final ferrite grain size of about 15-20 $\mu \mathrm{m}$ (ASTM 8-9) if recrystallized rolling is only used. If some level of nonrecrystallized rolling can be realized, then the $30-40 \mu \mathrm{m}$ grain can be elongated to various levels, depending on total deformation below the $\mathrm{Tnr}$ to $\leq 11 \mu \mathrm{m}$ (ASTM 10-12).

The critical reduction at a per pass deformation of $>15 \%$ if possible, should occur when the thickness in rolling is about $50-60 \%$ of that of the original starting thickness. This will result in the desired $30-40 \mu \mathrm{m}$ austenite grain size from surface to center. So if the starting billet thickness is $130 \mathrm{~mm}$, then a desired $15 \%$ reduction or more should occur in the rolling stand where the exit thickness is $52-65 \mathrm{~mm}$. Figure 12 shows the effect of a $15 \%$ reduction on the austenite grain size vs. the percentage of reduction during recrystallized rolling.

\footnotetext{
* Technical contribution to the 51st Rolling Seminar - Processes, Rolled and Coated Products, October $28^{\text {th }}$ to $31^{\text {st }}, 2014$, Foz do Iguaçu, PR, Brazil.
} 


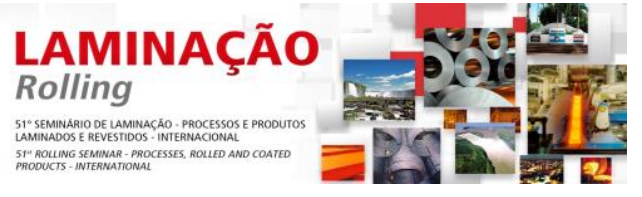

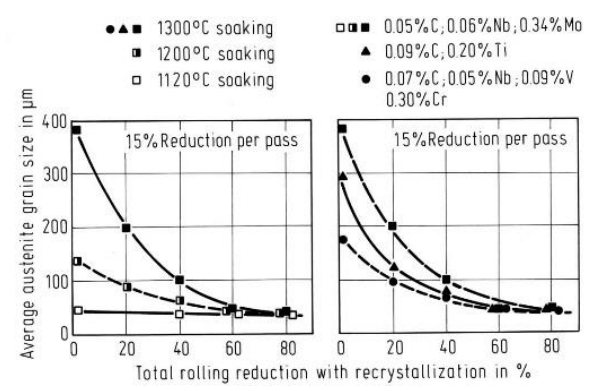

Figure 12. Total reduction in recrystallized rolling vs. final average austenite grain size

Figure 13 shows the effect of the amount of deformation below the non-recrystallized temperature region (Tnr) versus the final transformed ferrite grain size versus the starting austenite recrystallized grain size. It can easily be seen that if a fine enough recrystallized austenite grain can be realized, then with just a small amount of nonrecrystallized deformation an even finer ferrite grain can be produced.

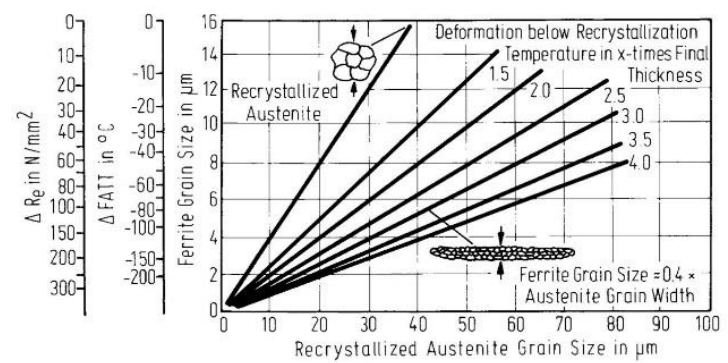

Figure 13. Non-recrystallized deformation vs. final ferrite grain size vs. starting recrystallized austenite grain size.

\section{CASE EXAMPLES}

The following are three actual production case examples in the production of heavy gauge angles requiring higher strength and toughness and medium gauge $\mathrm{H}$-beams with increased toughness. Both use the basic concepts previously discussed to achieve an optimum grain size to achieve the desired mechanical properties:

Angle Example - 250x250x30 and $32 \mathrm{~mm}$

Chemistry design can be seen in Table 3 with the appropriate key process parameter temperatures.

Table 3: Chemistry design

\begin{tabular}{|c|c|c|c|c|c|c|c|c|c|c|c|c|c|}
\hline $\mathrm{C}$ & $\mathrm{Si}$ & $\mathrm{Mn}$ & $\mathrm{N}$ & $\mathrm{V}$ & $\mathrm{Nb}$ & $\mathrm{Ti}$ & $\mathrm{Al}$ & $\begin{array}{c}\mathrm{NbCN} \\
\text { Soln }\end{array}$ & $\begin{array}{c}\mathrm{NbC} \\
\mathrm{Soln}\end{array}$ & $\begin{array}{c}\mathrm{Nb} \text { in } \\
\text { Soln }\end{array}$ & $\begin{array}{c}\mathrm{Tnr} \\
\mathrm{B} / \mathrm{DGS}\end{array}$ & $\begin{array}{c}\mathrm{Tnr} \\
\mathrm{Bai}\end{array}$ & $\mathrm{Ar}_{3}$ \\
\hline .10 & .20 & 1.50 & .012 & .070 & .030 & .020 & .025 & 1155 & 1097 & .030 & 939 & 937 & 766 \\
\hline
\end{tabular}

In this example, the desired reheat temperature by the mill due to rolling mill equipment capabilities was $1220^{\circ} \mathrm{C}$, so all $\mathrm{Nb}$ was in solution and austenite grain size control during reheating was accomplished with TiN precipitates. The mill layout along with a simple top water spray cooling upon the mill exit can be seen in Figure 14.

\footnotetext{
* Technical contribution to the 51st Rolling Seminar - Processes, Rolled and Coated Products, October $28^{\text {th }}$ to $31^{\text {st }}, 2014$, Foz do Iguaçu, PR, Brazil.
} 


\section{LAMINAÇÃO}

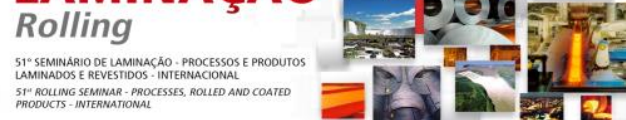
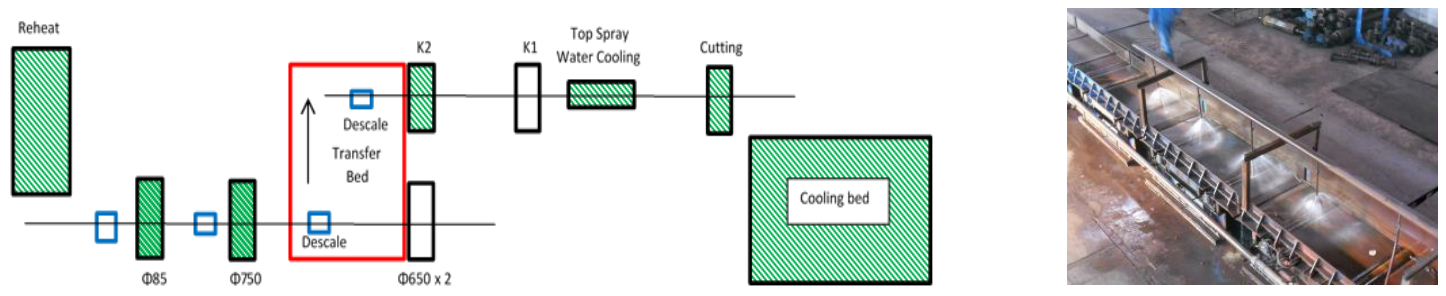

Figure 14. Angle mill layout and simple top water post rolling cooling

The reduction schedule per pass can be seen in Figure 15. Rolling passes 2 and 3 represented the $60 \%$ recrystallized rolling critical thickness and hence the largest reductions, however, note that many of the reductions per pass were robust, $>15 \%$ which is desirable for heavy gauge mechanical property performance. The finish rolling temperature was $\sim 900^{\circ} \mathrm{C}$ which based on the calculated Tnr temperatures resulted in about $25-30 \%$ reduction in the non-recrystallized rolling region. Post rolling cooling was used to help reduced the temperature down to about $800^{\circ} \mathrm{C}$ prior to the cooling bed allowing for precipitation strengthening to occur for the $\mathrm{Nb}$ and $\mathrm{V}$.

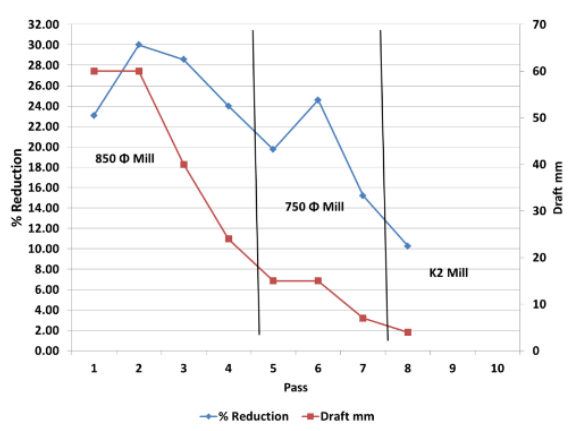

Figure 15. Reduction/drafting schedule for $250 \times 250 \times 30 / 32 \mathrm{~mm}$ angle. Note the heavy reductions in critical thickness range in passes 1 and 2 .

The final mechanical properties and microstructure can be seen in Table 4 and Figure 16. The $1 / 4$ thickness microstructure consisted of polygonal ferrite and pearlite with a grain size in the 10-20 $\mu \mathrm{m}$ range (ASTM 9-10). As can be seen yield strength exceeded $420 \mathrm{MPa}$ and charpy toughness was very good down to $-20^{\circ} \mathrm{C}$.

Table 4: Mechanical property results

\begin{tabular}{|c|c|c|c|c|c|c|}
\hline Dimension & \multicolumn{3}{|c|}{ Strength MPa } & \multicolumn{3}{c|}{ Average Transverse Charpy Energy J } \\
\cline { 2 - 7 } $\mathrm{mm}$ & Yield & Tensile & $\mathrm{A} \% 50 \mathrm{~mm}$ & $20^{\circ} \mathrm{C}$ & $0{ }^{\circ} \mathrm{C}$ & $-20^{\circ} \mathrm{C}$ \\
\hline $250 \times 250 \times 30$ & 445 & 580 & 28 & 163 & 104 & 132 \\
\hline $250 \times 250 \times 32$ & 440 & 580 & 27 & 128 & 81 & 54 \\
\hline
\end{tabular}

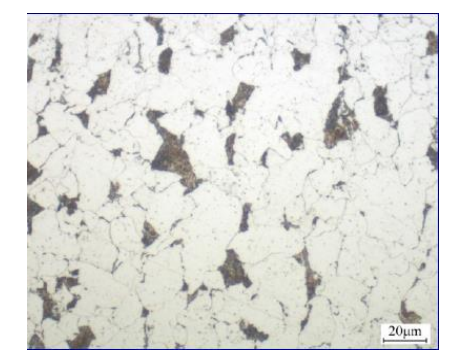

Figure 16. Microstructure/grain size, ASTM 7-8 (20-30 $\mu \mathrm{m})$

\footnotetext{
* Technical contribution to the 51st Rolling Seminar - Processes, Rolled and Coated Products, October $28^{\text {th }}$ to $31^{\text {st }}, 2014$, Foz do Iguaçu, PR, Brazil.
} 


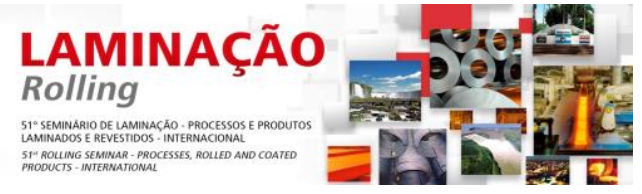

\subsection{H-beam Example}

In this case, a study using a single stand reversing roughing mill followed by a 3 stand universal mill with no post rolling cooling was done. This study compares:

i. the effect of the niobium at 2 different levels at a constant finish rolling temperature.

ii. the effect of different finish rolling temperatures with a constant Niobium level.

Table 5 shows varying niobium levels for the same thickness flange. Table 6 shows the resultant mechanical properties with identical rolling strategies. Figure 17 shows the obvious difference in microstructures of the two niobium levels with the higher niobium yielding better grain size which shows in the charpy toughness in Table 6 . Due to equipment limitations, a $1230^{\circ} \mathrm{C}$ reheat temperature is used, however as seen in Table 5 , in the case of the $0.030 \%$ Niobium level, all of the Niobium is in solution for some non-recrystallized deformation. However in the case of the $0.060 \mathrm{Nb}$ level, only $0.040 \mathrm{Nb}$ is in solution and the remaining is in the form of $\mathrm{NbCN}$ for austenite grain size control in the reheat furnace. In this case the $\mathrm{Nb}$ is playing two roles where as in the lower $\mathrm{Nb}$ case it is only playing one role. In each case, there is no titanium addition. Each had the same general finish rolling temperature of around $920{ }^{\circ} \mathrm{C}$. In the case of $0.030 \mathrm{Nb}$ and the relative finish temperature there was some nonrecrystallized reduction, but it was minimal. In the case of the $0.060 \% \mathrm{Nb}$ there was a more significant amount of non-recrystallized reduction. Again, the two roles that the Niobium was playing can be easily seen in the charpy performance and microstructure/grain size.

Table 5: Chemistry for $15 \mathrm{~mm} \mathrm{H}$-beam

\begin{tabular}{|c|c|c|c|c|c|c|c|c|c|c|c|c|c|c|}
\hline ID & $\mathrm{C}$ & $\mathrm{Si}$ & $\mathrm{Mn}$ & $\mathrm{N}$ & $\mathrm{V}$ & $\mathrm{Nb}$ & $\mathrm{Ti}$ & $\mathrm{Al}$ & $\begin{array}{c}\text { NbCN } \\
\text { Soln } \\
\text { Temp }\end{array}$ & $\begin{array}{c}\text { NbC } \\
\text { Soln } \\
\text { Temp }\end{array}$ & $\begin{array}{c}\text { Nb in } \\
\text { Soln }\end{array}$ & $\begin{array}{c}\text { Trr } \\
\text { B/DGS }\end{array}$ & $\begin{array}{c}\text { Tnr } \\
\text { Bai }\end{array}$ & $\mathrm{Ar}_{3}$ \\
\hline $0.030 \mathrm{Nb}$ & .14 & .14 & 1.22 & .007 & .001 & .031 & .001 & .030 & 1138 & 1197 & .031 & 974 & 961 & 769 \\
\hline $0.060 \mathrm{Nb}$ & .13 & .22 & 1.21 & .007 & .001 & .063 & .001 & .030 & 1303 & 1224 & .040 & 984 & 981 & 769 \\
\hline
\end{tabular}

Table 6: Mechanical property results

\begin{tabular}{|c|c|c|c|c|c|c|}
\hline \multirow{2}{*}{ ID } & \multicolumn{3}{|c|}{ Strength MPa } & \multicolumn{3}{c|}{ Longitudinal Charpy Energy J } \\
\cline { 2 - 6 } & Yield & Tensile & $\mathrm{A} \% 50 \mathrm{~mm}$ & \multicolumn{3}{c|}{$-2{ }^{\circ} \mathrm{C}$} \\
\hline $0.030 \mathrm{Nb}$ & 379 & 461 & 30 & 6 & 5 & 9 \\
\hline $0.060 \mathrm{Nb}$ & 375 & 546 & 27 & 112 & 125 & 103 \\
\hline
\end{tabular}

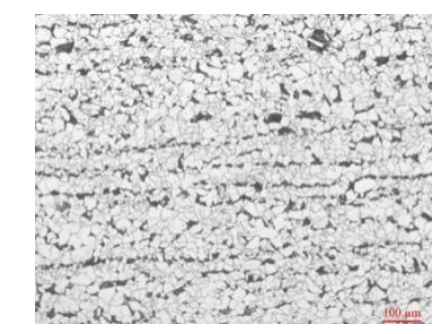

0.030 Nb, ASTM 6-8 (20-45 $\mu \mathrm{m})$

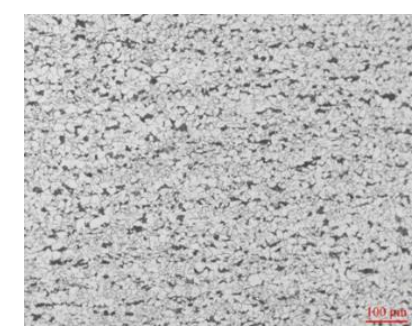

$0.060 \mathrm{Nb}$ ASTM $10-12(5-15 \mu \mathrm{m})$

Figure 17. Microstructure/grain size of $15 \mathrm{~mm}$ flange $\mathrm{H}$-beam with two different $\mathrm{Nb}$ levels.

In the second $\mathrm{H}$-beam case, the $\mathrm{Nb}$ is the same level at $0.050 \%$ and re-heat temperature is still $1230^{\circ} \mathrm{C}$ due to equipment capability issues and the $\mathrm{NbCN}$ for reheat austenite grain size control is the same with $0.008 \%$ not in solution. The difference is that one had a finish rolling temperature (FRT) that was only about $50^{\circ} \mathrm{C}$ below the $\mathrm{Tnr}$ and the second had a FRT $100^{\circ} \mathrm{C}$ below the $\mathrm{Tnr}$ resulting in

* Technical contribution to the 51st Rolling Seminar - Processes, Rolled and Coated Products, October $28^{\text {th }}$ to $31^{\text {st }}, 2014$, Foz do Iguaçu, PR, Brazil. 


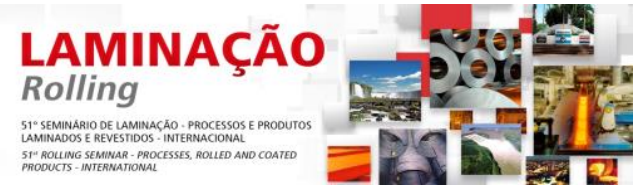

significantly different total percent reductions in the non-recrystallized rolling region. Based on the reheat temperature and $\mathrm{NbCN}$ not in solution one can assume that the starting austenite grain size for non-recrystallized deformation was the same. It can be seen that in both cases the charpy toughness and resultant microstructure is better than seen in the previous $\mathrm{H}$-beam example showing that controlling the reheat austenite grain size, even if it is only a small amount plus some small percentage of non-recrystallized deformation results in improve grain size and charpy performance. Table 7 and 8 show chemistry and mechanical properties and Figure 18 shows the microstructure/grain size comparison.

Table 7: Chemistry for 12/14 $\mathrm{mm} \mathrm{H}$-beam

\begin{tabular}{|c|c|c|c|c|c|c|c|c|c|c|c|c|c|c|}
\hline FRT & $\mathrm{C}$ & $\mathrm{Si}$ & $\mathrm{Mn}$ & $\mathrm{N}$ & $\mathrm{V}$ & $\mathrm{Nb}$ & $\mathrm{Ti}$ & $\mathrm{Al}$ & $\begin{array}{c}\mathrm{NbCN} \\
\text { Soln } \\
\text { Temp }\end{array}$ & $\begin{array}{c}\text { NbC } \\
\text { Soln } \\
\text { Temp }\end{array}$ & $\begin{array}{c}\mathrm{Nb} \\
\text { in } \\
\text { Soln }\end{array}$ & $\begin{array}{c}\text { Tnr } \\
\text { B/DGS }\end{array}$ & $\begin{array}{c}\text { Tnr } \\
\text { Bai }\end{array}$ & $\mathrm{Ar}_{3}$ \\
\hline $\begin{array}{c}12 \mathrm{~mm}, \\
930^{\circ} \mathrm{C}\end{array}$ & .13 & .18 & 1.23 & .007 & .001 & .051 & .001 & .030 & 1259 & 1188 & .043 & $1002^{*}$ & 981 & 771 \\
\hline $\begin{array}{c}14 \mathrm{~mm}, \\
860^{\circ} \mathrm{C}\end{array}$ & .12 & .13 & 1.25 & .007 & .001 & .048 & .001 & .030 & 1212 & 1149 & .040 & $1000^{*}$ & 969 & 772 \\
\hline
\end{tabular}

${ }^{*}$ From experience values at $1000 \mathrm{C}$ and higher are not realistic in controlling non-recrystallization in production.

Table 8: Mechanical property results

\begin{tabular}{|c|c|c|c|c|c|c|}
\hline \multirow{2}{*}{ FRT } & \multicolumn{3}{|c|}{ Strength MPa } & \multicolumn{3}{c|}{ Longitudinal Charpy Energy J } \\
\cline { 2 - 6 } & Yield & Tensile & A\% $50 \mathrm{~mm}$ & \multicolumn{3}{c|}{$-20^{\circ} \mathrm{C}$} \\
\hline $12 \mathrm{~mm}, 930^{\circ} \mathrm{C}$ & 398 & 511 & 28 & 79 & 80 & 66 \\
\hline $14 \mathrm{~mm}, 860^{\circ} \mathrm{C}$ & 436 & 536 & 29 & 168 & 136 & 159 \\
\hline
\end{tabular}
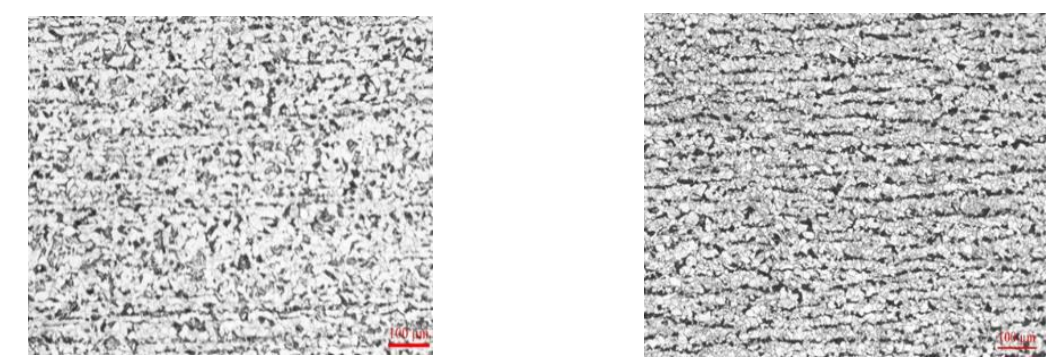

$12 \mathrm{~mm}, 930^{\circ} \mathrm{C}$, ASTM $8(20-25 \mu \mathrm{m}) \quad 14 \mathrm{~mm}, 860^{\circ} \mathrm{C}$, ASTM 10-12 $(5-15 \mu \mathrm{m})$

Figure 18. Microstructure/grain size of 12 and $14 \mathrm{~mm}$ flange $\mathrm{H}$-beam with two different FRT with same $\mathrm{Nb}$ levels

\section{CONCLUSION}

Final transformed cross sectional grain size is the foundation of the metallurgy created in long/structural steels. With proper control of microalloy design, processing temperatures, deformations and cooling, a finer cross sectional ferrite grain size can be developed resulting in optimum strength and toughness. This can be accomplished even on equipment that has less than desirable capabilities as illustrated by the case examples. The key to this success is a thorough understanding of the metallurgy involved, particularly the proper use of niobium technology.

\footnotetext{
* Technical contribution to the 51st Rolling Seminar - Processes, Rolled and Coated Products, October $28^{\text {th }}$ to $31^{\text {st }}$, 2014, Foz do Iguaçu, PR, Brazil.
} 


\section{REFERENCES}

1 Lu J, Ivey D, Henein H, Wiskel J, Omotoso O. Extraction and Extraction of Nanoprecipitates in Microalloyed Steels. Proceedings of $7^{\text {th }}$ ASME International Pipeline Conference, Calgary Canada, 2008.

2 Stalheim D, Barnes K, McCutcheon D. Alloy Designs for High Strength Oil and Gas Transmission Linepipe Steels. Proceedings of CBMM-TMS International Symposium Microalloyed Steels for the Oil \& Gas Industry, Araxa, Brazil, 2006.

3 Repas PE. Metallurgical Fundamentals for HSLA Steels, USS Technical Center, Monroeville, PA, USA.

4 Stalheim D, Glodowski R. Production of Fine Grained As-rolled Plate Steels, Proceedings of ASITech 2009 Conference, Pittsburgh, PA, USA, 2009.

5 Stalheim D. A Practical Guide to Metallurgical Design for Rolled Structural Steels, Proceedings of ABM 50 ${ }^{\text {th }}$ Rolling Conference, Ouro Preto, Brazil, 2013.

6 Hulka K. Niobium Microalloyed Plate Products for Welded Construction, CBMM/CITIC Metal Short Course, Beijing, China, 2006.

7 Ding W, Jiang Z, Bai X, Li S, Zha C, Li J et al. Research and Development into Low Temperature Toughness of Large Diameter Heavy Wall X80 Pipeline Steel at Shougang Steel. Proceedings of $9^{\text {th }}$ ASME International Pipeline Conference, Calgary Canada, 2008.

8 Cuddy L. The Effect of Microalloy Concentrations on the Recrystallization of Austenite during Hot Deformation. Thermomechanical Processing of Microalloyed Austenite, Warrendale, PA. TMS, 1982.

* Technical contribution to the 51st Rolling Seminar - Processes, Rolled and Coated Products, October $28^{\text {th }}$ to $31^{\text {st }}, 2014$, Foz do lguaçu, PR, Brazil. 